\title{
Higher mortality of the less suitable brown trout host compared to the principal Atlantic salmon host when infested with freshwater pearl mussel (Margaritifera margaritifera) glochidia
}

\author{
Janhavi Marwaha $^{1}$ (D) $\cdot$ Per Johan Jakobsen ${ }^{1} \cdot$ Sten Karlsson $^{2} \cdot$ Bjørn Mejdell Larsen ${ }^{2} \cdot$ Sebastian Wacker $^{2}$
}

Received: 4 October 2020 / Accepted: 30 March 2021 / Published online: 12 April 2021

(C) The Author(s) 2021

\begin{abstract}
The freshwater pearl mussel (Margaritifera margaritifera) is a highly host-specific parasite, with an obligate parasitic stage on salmonid fish. Atlantic salmon (Salmo salar) and brown trout (Salmo truttaf. trutta and Salmo truttaf. fario) are the only hosts in their European distribution. Some M. margaritifera populations exclusively infest either Atlantic salmon or brown trout, while others infest both hosts with one salmonid species typically being the principal host and the other a less suitable host. Glochidial abundance, prevalence and growth are often used as parameters to measure host suitability, with the most suitable host species displaying the highest parameters. However, it is not known if the degree of host specialisation will negatively influence host fitness (virulence) among different host species. In this study we examined the hypothesis that glochidial infestation would result in differential virulence in two salmonid host species and that lower virulence would be observed on the most suitable host. Atlantic salmon and brown trout were infested with glochidia from two M. margaritifera populations that use Atlantic salmon as their principal host, and the difference in host mortality among infested and control (sham infested) fish was examined. Higher mortality was observed in infested brown trout (the less suitable host) groups, compared to the other test groups. Genetic assignment was used to identify offspring from individual mother mussels. We found that glochidia from individual mothers can infest both the salmonid hosts; however, some mothers displayed a bias towards either salmon or trout. We believe that the differences in host-dependent virulence and the host bias displayed by individual mothers were a result of genotype $\times$ genotype interactions between the glochidia and their hosts, indicating that there is an underlying genetic component for this parasite-host interaction.
\end{abstract}

Keywords Margaritifera $\cdot$ Glochidia $\cdot$ Host-parasite $\cdot$ Virulence $\cdot$ Mortality $\cdot$ Host bias

\section{Introduction}

Parasites are typically classified as either being host specialists or host generalists depending on their host range; i.e. the former attain high fitness on very few host species compared to the latter, which attain it on many (Veiga et al. 1998; Poulin 2007; Leggett et al. 2013; Lievens et al. 2018). Host

Section Editor: Shokoofeh Shamsi

Janhavi Marwaha

janhavi_marwaha@yahoo.com

1 Department of Biology, University of Bergen, Thormøhlens Gate 53A, 5006 Bergen, Norway

2 Norwegian Institute for Nature Research (NINA), Postboks 5685 Torgarden, 7485 Trondheim, Norway specificity is both a reflection of the individual biological properties of the parasite and the host, as well as a result of the specific interaction between the two (Dick and Patterson 2007). Moreover, the degree of host specificity displayed by a parasite is believed to be a result of the historical associations between the parasite and its hosts and present ecological events (Dick and Patterson 2007; Poulin 2007). It is an important attribute of a parasite because it has an influence on its ecology and future evolution; for example, the ability of the parasite to adapt to new hosts (Poulin and Mouillot 2003; Salvaudon et al. 2007; Lievens et al. 2018). In order to understand how the degree of host specificity will influence parasitic fitness, and their survival in a changing environment, it is important to measure their fitness across different host species (Lievens et al. 2018).

Most studies on host-parasite relationships involve shortlived parasites. Host-parasite interactions involving a long- 
lived parasite, and the effect of these interactions on parasite fitness, are not well understood. Parasites are usually regarded as having a greater evolutionary potential and adaptive plasticity, resulting from them having larger population sizes, higher mutation rates and shorter generation times compared to their hosts (Ebert 1994; Kaltz and Shykoff 1998; Gandon and Michalakis 2002; Dybdahl and Storfer 2003). The freshwater pearl mussel (FPM), Margaritifera margaritifera, is an example of a long-lived specialist parasite with a reproductive lifespan that is 30 times longer than its host (Geist and Kuehn 2008), and it is a good model to examine the influence of high host specificity on parasite fitness, in particular virulence and infectivity (host bias).

M. margaritifera is a freshwater bivalve which belongs to the order Unionida, and like all unionid mussel species, it has a complex life cycle. The FPM life cycle includes an obligate parasitic stage on a suitable salmonid host (Smith 1976; Meyers and Milleman 1977; Young and Williams 1984a). Parasitic glochidia $(60-80 \mu \mathrm{m})$ released by gravid mothers reach a fish host passively by drifting with the water current and are encysted by gill epithelial cells of a suitable host (Young and Williams 1984a; Bauer 1987). Infective glochidia are not selective during attachment and are able to attach to all objects (e.g. wood, plastic or paper) (Kat 1984; Dodd et al. 2005), but in order to be encysted by gill epithelial cells of the host, they must induce an immune response (Nezlin et al. 1994; Jansen et al. 2001). Glochidia that are unable to induce an immune response are shed off (Nezlin et al. 1994). Hostparasite compatibility is believed to be an underlying factor that influences successful glochidial encystment on suitable hosts, duration of the parasitic phase and post-parasitic performance of juvenile mussels (Haag 2012; Marwaha et al. 2017; Taeubert and Geist 2017). After a parasitic period lasting between 9 and 11 months, free-living juvenile mussels excyst and spend the next 5 years buried in the river substratum (Smith 1976; Bauer 1987).

Unionid mussel species display varying degrees of host specificity. This can range from host generalists, such as Anodonta species that metamorphose on several host species, to highly host-specific ones, such as those of the family Margaritiferidae that can develop only on a few closely related host species (Bauer 2001; Strayer et al. 2004). M. margaritifera displays a high degree of specialisation, and Atlantic salmon (Salmo salar) and brown trout (Salmo trutta f. fario and Salmo trutta f. trutta) are their only hosts in their European distribution (Young and Williams 1984b). Some FPM populations can exclusively infest either Atlantic salmon ('salmon-mussels') or brown trout ('trout-mussels') even when both host species are present (Larsen et al. 2000; Hastie and Young 2001; Karlsson et al. 2014; Österling and Wengström 2015; Salonen et al. 2017; Wacker et al. 2019); whereas others infest both salmonid host species but with varying degrees of suitability (Taeubert et al. 2010; Salonen et al. 2017; Taeubert and Geist 2017; Clements et al. 2018). Highly host-specific FPM populations have been observed in rivers in Ireland (Geist et al. 2018), Scotland (Hastie and Young 2001), Sweden (Österling and Wengström 2015) and Norway (Larsen et al. 2012; Karlsson et al. 2014; Wacker et al. 2019). High host specificity has also been observed in artificial infestation experiments, in which salmon- or troutmussels, exposed to both salmonid host species in the same infestation tank, only infested the principal salmonid host (Larsen et al. 2012; Österling and Wengström 2015; Wacker et al. 2019). In FPM populations that infest both salmonid hosts (i.e. a principal and a less suitable host), it is not clear if glochidia from specific families exclusively infest either brown trout or Atlantic salmon or if offspring from the same family can infest both the salmonid hosts. Host suitability studies, which determine the salmonid species requirements of a particular FPM population, provide the essential information required for conservation efforts such as artificial breeding programmes and re-stocking of suitable hosts in FPM rivers (Salonen et al. 2017; Taeubert and Geist 2017; Clements et al. 2018).

Glochidia take 9-11 months to metamorphose, and glochidial survival depends on host survival for this entire duration. In the FPM host-parasite relationship, the parasite is expected to experience a stronger selection pressure on compatible host genotypes because its survival depends on host compatibility (Douda et al. 2017). In comparison, the hosts are expected to experience a weaker selection for resistance to glochidia (Douda et al. 2017). This is because the parasite is distributed across a smaller area of the host's total distribution range, and it infests only the freshwater (young) stage of the host (Douda et al. 2017). However, glochidial infestation has a negative effect on the host and causes an increase in blood haematocrit values, spleen enlargement, respiratory stress and impaired swimming (Taeubert and Geist 2013; Horký et al. 2014; Thomas et al. 2014; Douda et al. 2017; Filipsson et al. 2017; Marwaha et al. 2019). Typically, low to moderate glochidial infestation has no significant detrimental effect on hosts, while high glochidial loads can lead to host mortality (Treasurer et al. 2006; Taeubert and Geist 2013). However, previous studies have shown that glochidial densities which were within the recommended range on a host fish (5-100 per gram fish) (Taeubert and Geist 2013) resulted in respiratory stress (Thomas et al. 2014; Marwaha et al. 2019). Thus, the resulting cost of infestation to the host suggests that pearl mussel glochidia are indeed a selective force, and this can result in potential mussel-salmonid host coevolution (Douda et al., 2017; Chowdhury et al. 2019).

Virulence is defined as the reduction in host fitness (mortality) as a result of parasitic infestation (Bull 1994; Read 1994; Dybdahl and Storfer 2003; Lambrechts et al. 2006; Bieger and Ebert 2009). Parasitic virulence is not a trait of the parasite alone but is believed to be a result of either a 
parasite's adaptive strategy, host response to parasite infestation, or a complex interaction between these two (Ewald 1983; Mackinnon et al. 2002, Day and Burns 2003; Perlman and Jaenike 2003). Some studies have shown that a parasite can cause differential virulence or mortality among closely related host species (Thomas et al. 1995; Hurst and Bartholomew 2012; Lievens et al. 2018). Lievens et al. (2018) observed differential virulence of a microsporidian parasite (Anostracospora rigaudi) among two species of brine shrimp (Artemia parthenogenetica and Artemia franciscana). This was dependent on the degree of compatibility between the parasite and the host. Differences in host species (and strain) susceptibility to different FPM populations are well documented. To the best of our knowledge, host speciesdependent differences in glochidial virulence (mortality) in FPM have not been examined.

The purpose of this study was to investigate if there was a difference in mortality between brown trout and Atlantic salmon that have been infested with salmon-mussel glochidia. We hypothesised that glochidial virulence, measured as host mortality, would be higher on the less suitable brown trout host. We also examined variation in the infestation success of offspring from individual mother mussels on the two salmonid hosts. We hypothesised that individual FPM mothers can infest both host species, but with varying degrees of success. In order to test our hypotheses, we used glochidia from two FPM populations that have been observed to use Atlantic salmon as the principal host, to infest both Atlantic salmon and brown trout (Johnsen et al. 2008; Eilertsen et al. 2018). We used hatchery-reared (naïve) fish of the same age in our experiment. This might be expected to limit the possible effects from local genetic adaptation in the host. However, we cannot completely discount the possibility that the fish used were more adapted to either salmon- or trout-mussels. We recorded host species-dependent mortality during the parasitic phase of the glochidia. We also recorded the total number of juveniles that excysted from Atlantic salmon and brown trout. Using parentage analysis, we examined whether individual mothers infested both hosts and whether infestation was biased towards one or the other host species.

\section{Materials and methods}

Host infestation experiments were performed at the FPM rearing station at Austevoll, Norway. Lake Kvernavatnet provides the water supply for the rearing station, and the water has a $\mathrm{pH}$ of 6.6 and alkalinity of $0.108 \mathrm{mmol} / \mathrm{l}$, and the concentrations of aluminium, iron, calcium, magnesium and nitrate were as follows: Al $180 \mu \mathrm{g} / \mathrm{l}, \mathrm{Fe} 200 \mu \mathrm{g} / \mathrm{l}$, $\mathrm{Ca} 4.2 \mathrm{mg} / \mathrm{l}, \mathrm{Mg} 1.8 \mathrm{mg} / \mathrm{l}, \mathrm{Na} 12 \mathrm{mg} / \mathrm{l}$ and Nitrate-N $0.15 \mathrm{mg} / \mathrm{l}$. All incoming water was UV-treated and filtered through a $30-\mu \mathrm{m}$ mesh before use.

\section{Glochidial collection}

Adult mussels were collected from the rivers Slørdalselva ( $n=$ 52; Orkland municipality, Trøndelag county) and Loneelva ( $n$ $=40$, Osterøy municipality, Vestland county) in August 2015 and April 2014, respectively. Fertilisation of Slørdalselva FPM took place in the wild, whereas those from Loneelva were fertilised at the FPM rearing station. Both these FPM populations use Atlantic salmon as the principal host (Johnsen et al. 2008). The mussels were transferred to the FPM rearing station and placed in artificial rivers with flowing water. They were fed regularly with a diet containing Shellfish ${ }^{\circledR} 1800$ (Reed Mariculture Inc., Campbell, CA, USA) and Nanno 3600 (Reed Mariculture Inc.). Gravid mussels started spatting in September 2015 at a mean water temperature of $15.7^{\circ} \mathrm{C}$. Glochidial strings were collected from spatting individuals and checked for maturation and viability ( $\geq 90 \%$ ), using methods described by Watters and O'Dee (1999), before we used them to infest the host fish.

\section{Fish infestation}

Naïve hatchery-reared 0+ Atlantic salmon (Bjoreio, Vestland county, standard length $10.3 \pm 7.1 \mathrm{~cm}$ ) and brown trout (Botsvann, Agder county, standard length $11.3 \pm 4.8 \mathrm{~cm}$ ) from the Statkraft facility in Eidfjord municipality were transferred to the FPM rearing station in July 2015. The fish were kept in aerated tanks and fed until satiated. Before infesting the hosts with glochidia, 200 Atlantic salmon and 200 brown trout each, were transferred into three 40001 (height, length, width $=1 \mathrm{~m}$ $\times 2 \mathrm{~m} \times 2 \mathrm{~m}$ ) tanks: one as a control group and the other two as the infestation groups for the two FPM populations (Fig. 1). Infestation of the fish took place in September 2015. In order to infest the fish, we lowered the water levels in the tank and exposed the fish to glochidia (500 glochidia/l) for a period of 40 min with aeration (Taeubert et al. 2010). For the control groups, sham infestations were performed by exposing them to the same infestation conditions as the test groups, but without the presence of glochidia. All the groups (tests and control) were maintained under equal temperature and food conditions for the duration of the encystment period.

Post infestation, the fish were monitored daily, for number of mortalities, until the 18th of May 2016. Infestation status (presence/absence of glochidia) was recorded for a subsample of the fish that died (35-48\% per host species and FPM population). The infestation status of the dead fish was examined by opening the gill flap and looking for the presence/absence of glochidia on all four gill arches. In addition, the gills were also examined under a dissecting microscope to confirm the infestation status. On the 18th of May 2016, the infestation status of all surviving fish exposed to Loneelva glochidia and of a random subsample of the fish exposed to Slørdalselva glochidia (44\% of surviving trout and $87 \%$ of surviving 
salmon) was examined. Infestation status of the live fish, i.e. the presence/absence of glochidia, was checked only on the first two gill arches. Fish were first sedated with AQUI-S $(2.5 \mathrm{mg} / \mathrm{l}$ for $15 \mathrm{~min})$, and then the gill flap was gently lifted to check for the presence/absence of glochidia. This was done visually, because it is easy to see encysted glochidia 9 months post infestation.

Since the live fish were checked very briefly for the presence of glochidia, it is likely that low levels of glochidial infestations were recorded as no infestation observed. Therefore, all fish exposed to glochidia were used to collect juvenile mussels. On 25 May 2016, fish exposed to glochidia were sorted and then transferred to separate juvenile mussel collecting chambers (90 1), i.e. one for trout and one for salmon. Fish were maintained in these tanks until the end of the excystment period, following the methodology originally described by Hruska (1999). Of the surviving fish, 76 out of 153 Atlantic salmon, and all the surviving $(n=100)$ brown trout exposed to glochidia from Slørdalselva were transferred into the mussel collecting chambers. The $200-\mu \mathrm{m}$ collection sieves, under the collecting chambers, were inspected daily for the presence of excysted juvenile mussels, and mussels that excysted were collected and counted in order to get the total number of juvenile mussels that excysted from the salmon and trout harvesting chambers.

In order to calculate the infestation success of individual mothers on the two salmonid host species, we used fish infested with mussels from Slørdalselva. Juvenile mussels that excysted from Atlantic salmon and brown trout $(n=100$ per host species) were collected in June and September 2016 for genetic analysis. Individual mussels were put into an
Eppendorf tube containing 95\% ethanol. Visceral swabs were taken for DNA collection from adult brood-mussels (parents) and stored in lysis buffer for later genetic analyses as explained by Karlsson et al. (2013).

\section{Genetic analysis}

Genetic analysis was done at the Norwegian Institute for Nature Research (NINA). DNA was extracted from the whole animal for juveniles and from cotton swabs for adults using DNeasy tissue kits (Qiagen). Mussels were genotyped at 15 microsatellite loci: MarMa3050, MarMa3621, MarMa4277, MarMa4322, MarMa2671, MarMa4143 and MarMa5280 (Geist et al. 2003) and Mm2201, Mm2230, Mm2235, Mm2240, Mm2207, Mm2210 and Mm2233, Mm2236 (Garlie 2010). PCR was carried out in two multiplexes (Karlsson et al. 2016). The following PCR protocol was used: 2- $\mu$ l DNA, 4- $\mu$ l Qiagen Multiplex Mastermix, 0.8- $\mu$ l Primermix and 1.6- $\mu$ l RNase-free water (Karlsson et al. 2016). The PCR was run on a Quattro Cycler (VWR) in the following conditions: denaturation for $15 \mathrm{~min}$ at $95{ }^{\circ} \mathrm{C}$, followed by 30 cycles of $57{ }^{\circ} \mathrm{C}$ for $90 \mathrm{~s}$ and $72{ }^{\circ} \mathrm{C}$ for $60 \mathrm{~s}$, and a final step of $60^{\circ} \mathrm{C}$ for $30 \mathrm{~min}$ (Karlsson et al. 2016). For each multiplex, PCR products were visualised separately on an ABI 3130xl DNA analyser (Applied Biosystems) and sized using GENEMAPPER ver. 3.7 (Applied Biosystems).

\section{Assignment of offspring to mothers}

Offspring were assigned to mothers using the likelihoodbased approach in CERVUS 3.0 (Kalinowski et al. 2007).
Fig. 1 Schematic overview of the methods used in this experiment

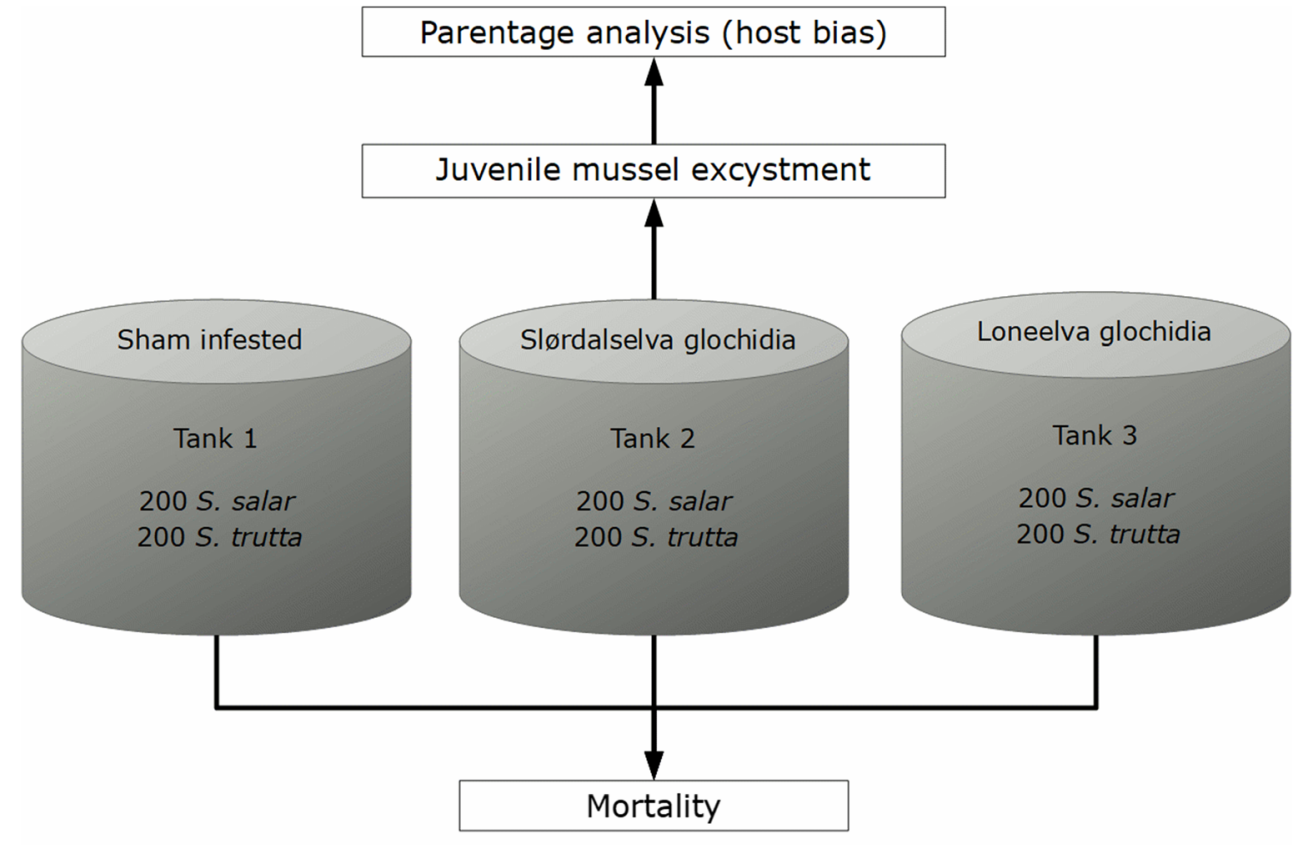

All tanks were maintained under similar temperature and food regimes 
Adults were collected from the river after fertilisation had taken place. The collected adults were therefore known to include all mothers, while only an unknown fraction of fathers was collected. We first assigned parentage for offspring for which both the mother and the father had been sampled, using a parent pair analysis with unknown sex. We then performed a maternity analysis with complete sampling of maternal genotypes to assign the remaining offspring to mothers. All parentage analysis in CERVUS was performed with a mistyping rate of 0.01 and a critical Delta value for parentage assignment set for a confidence level of $95 \%$. The sex of adults was inferred from assigned parentage. Adults that were assigned parentage in maternity analysis only, or in both maternity and parental pair analyses, were classified as females. Adults that were assigned parentage in parental pair analysis only were classified as males. Details of parentage analysis are presented in Wacker et al. (2018).

\section{Statistical analysis}

We used the statistical package $\mathrm{R}$, version 3.4.3 (R Core Team, 2017), for all statistical analysis. We used Fisher's exact test to examine the probability of observing higher mortality in the exposed salmon and trout groups, when compared with control salmon and trout groups, respectively. This was performed separately for both Slørdalselva and Loneelva. We used a chi-square test to examine the null hypothesis that individual mothers infest both the host species with equal probability.

\section{Results}

\section{Host mortality}

Brown trout exposed to glochidia, from both the FPM populations, displayed a higher mortality compared to Atlantic salmon as well as control fish (Table 1). In Slørdalselva, the odds of an Atlantic salmon exposed to glochidia dying was 2.61 times that of a salmon in the control group (Fisher's test: $p$-value $=<0.001$, odds ratio $=2.61$; Fig. 2 ). However, the odds of a brown trout exposed to glochidia dying was 10.69 times that of a trout dying in the control group (Fisher's test: $p$ - value $<0.001$, odds ratio $=10.69 ;$ Fig. 2 ). In addition, the odds of a trout dying as a result of exposure to glochidia was 3.25 times that of a salmon dying when exposed to them (Fisher's test: $p$-value $<0.001$, odds ratio $=3.25$ ). For Loneelva, we did not find any difference in the mortality of salmon exposed to glochidia and the control group (Fisher's test: $p$-value $=$ 0.6095 , odds ratio $=0.7922$, Fig. 2). However, the odds of a trout exposed to glochidia dying was 8.41 times that of a trout dying in the control group (Fisher's test: $p$-value $<0.001$, odds ratio $=8.41$, Fig. 2). Similar to the previous result, the odds of a trout dying when exposed to glochidia was 8.41 times that of a salmon dying when exposed to them (Fisher's test: $p$-value $=$ $<0.001$, odds ratio $=8.41$ ) .

In our subsamples, a higher percentage of salmon were infested with glochidia compared to trout. In Slørdalselva, $73 \%$ of the salmon and $54 \%$ of the brown trout were infested, and in Loneelva $51 \%$ of the salmon and $32 \%$ of the trout were infested (Fig. 3). In Slørdalselva, the odds of a salmon becoming infested with glochidia, when exposed to them, was 2.23 times higher than a trout becoming infested (Fisher's test: $p$ value $=0.005$, odds ratio $=2.23$ ). In Loneelva, the odds of a salmon becoming infested was 2.82 times that of a trout becoming infested (Fisher's test: $p$-value $=0.0002$, odds ratio $=$ 2.82). In addition, when we examined only the infested fish in all the groups, we observed that a higher percentage of infested trout died compared to infested salmon. In Slørdalselva, $12 \%$ of the infested salmon versus $82 \%$ of the infested trout died. In Loneelva, $2 \%$ of the infested salmon versus $65 \%$ of the infested trout died (Fig. 4). In Slørdalselva, the odds of a trout dying as a result of glochidial infestation was 32.41 times that of a salmon dying due to it (Fisher's test: $p$-value $<0.001$, odds ratio $=32.41$ ). In Loneelva, the odds of a brown trout dying as a result of infestation was 83.54 times that of a salmon dying as a result of it (Fisher's test: $p$-value < 0.001 , odds ratio $=83.54$ ).

\section{Host bias}

The total number of juvenile Slørdalselva mussels collected from the harvesting chamber after the experiment was 23,780 for mussels that had developed on 76 Atlantic salmon and 14,909 for mussels that had developed on 100 brown trout. Consequently, the average number of juvenile mussels
Table 1 The total number of fish exposed to glochidia, total dead and total alive for the rivers Slørdalselva and Loneelva

\begin{tabular}{llllllll}
\hline \multirow{2}{*}{ Number of fish } & \multicolumn{2}{l}{ Atlantic salmon } & & \multicolumn{2}{l}{ Brown trout } \\
\cline { 2 - 3 } & Control & Slørdalselva & Loneelva & & Control & Slørdalselva & Loneelva \\
\hline Total exposed & 200 & 200 & 200 & & 200 & 200 & 200 \\
Total dead & 21 & 47 & 17 & & 17 & 100 & 88 \\
Total alive & 179 & 153 & 183 & & 183 & 100 & 112 \\
\hline
\end{tabular}


harvested per surviving fish was about two times higher for Atlantic salmon (313 juveniles/fish) compared to that of brown trout (149 juveniles/fish). Our results showed that individual mussel mothers from Slørdalselva infested both Atlantic salmon and brown trout. When 100 juvenile mussels collected from Atlantic salmon and 100 juvenile mussels collected from brown trout were assigned to individual mothers, mothers differed in the proportion of glochidia that infested Atlantic salmon and brown trout, respectively $(\chi 2=40.141$; $\mathrm{df}=14, p$-value $=0.0002$, Fig. 3 ). For the majority of individual mothers, similar numbers of assigned offspring were collected from Atlantic salmon and from brown trout, but for some individuals, there was a strong bias (mothers A, M, N and $\mathrm{O}$ in Fig. 5).

\section{Discussion}

The results of this study show that glochidial infestation resulted in host species-dependent mortality, in agreement with the hypothesis that virulence would be lower on the most suitable host. Brown trout exposed to and infested with glochidia displayed a significantly higher mortality compared to Atlantic salmon exposed to glochidia and the control groups. This was observed in both the FPM populations. In line with observations by Johnsen et al. (2008) and Eilertsen et al. (2018), Atlantic salmon was the most suitable host for Slørdalselva and Loneelva, and we observed that a higher proportion of salmon were infested compared to that of trout in both these rivers. In addition,

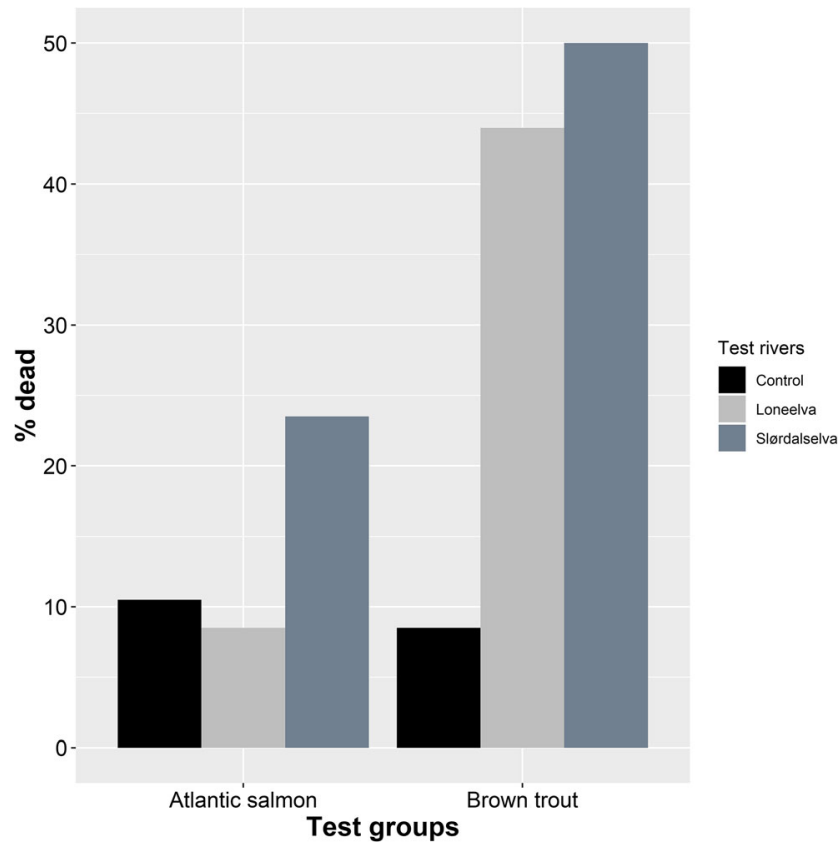

Fig. 2 Bar plot showing the difference in host mortality (\% dead) between the control Atlantic salmon and brown trout and those exposed to glochidia from the rivers Slørdalselva and Loneelva

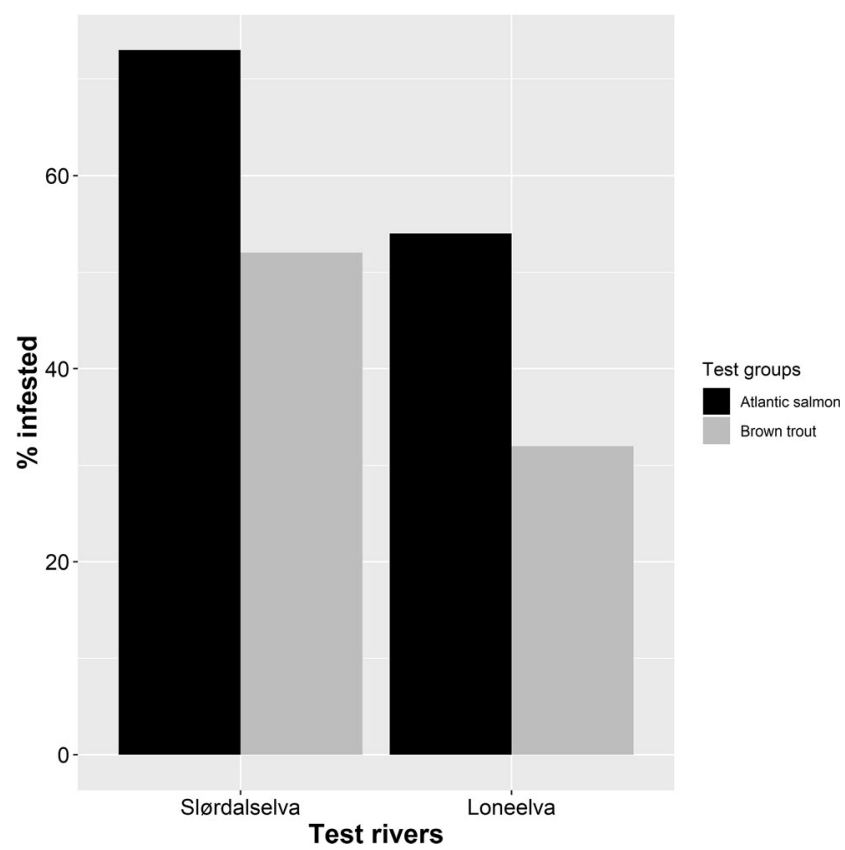

Fig. 3 Bar plot showing the percentage of infested fish in the subsamples from Slørdalselva and Loneelva. In Slørdalselva, 73\% of the salmon (109 out of 150 checked) and $54 \%$ of the brown trout (50 out of 92 checked) were infested. In Loneelva, $51 \%$ of the salmon (98 out of 189 checked) and $32 \%$ of the brown trout (48 out of 150 checked) were infested

Slørdalselva salmon also had the highest average number of excysted juvenile mussels per surviving host fish. Mussels primarily infested Atlantic salmon, but this bias varied

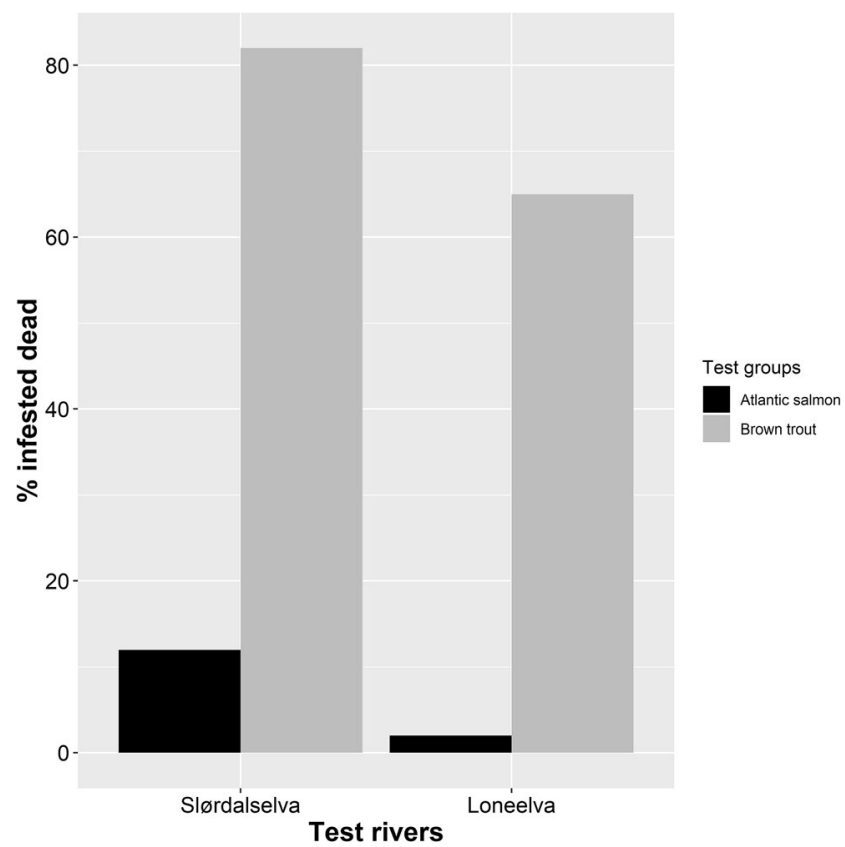

Fig. 4 Bar plot of infested fish that died, shown as a percentage of the total number of infested fish. In Slørdalselva, $12 \%$ of the infested salmon (13 dead infested; 96 alive infested) and $82 \%$ of the infested trout (41 dead infested; 8 alive infested) died. In Loneelva, $2 \%$ of the infested salmon ( 2 dead infested; 98 alive infested) and $65 \%$ of the infested trout (31 dead infested; 48 alive infested) died 
between mothers, and some individual mothers infested brown trout to a higher degree compared to Atlantic salmon. Individual mussels may therefore produce offspring that can utilise both brown trout and Atlantic salmon, and not exclusively infest one or the other. This observation indicates that there is a large evolutionary potential for a shift in principal host where both hosts are being utilised to some extent.

The fitness of specialist parasites will often vary among different hosts depending on their suitability, and this can range from high fitness to zero fitness (Poulin 2007; Lefèvre et al. 2008; Schmid-Hempel 2011; Lievens et al. 2018). This has also been observed in several FPM studies, where glochidial fitness (quantitatively measured as abundance, prevalence and growth) was highest on the most suitable salmonid host species (Taeubert et al. 2010; Salonen et al. 2017;
Taeubert and Geist 2017; Clements et al. 2018). Moreover, the results of this study have shown that glochidial virulence (host mortality) also varied among the two salmonid host species and was dependent on host suitability. However, the quantitative and qualitative (juvenile growth, lipid reserves) traits for measuring host suitability are not always correlated and can vary significantly between host species and between individuals of a suitable species (Taeubert et al. 2010; Douda 2015). For example, Douda (2015) observed that juveniles of Unio crassus and Anodonta anatina that developed on different host species, as well as individuals of a host species, varied in their lipid reserves as well as their early post-larval growth. In addition, they also observed that juveniles of A. anatina had the highest lipid levels on hosts with the lowest transformation success. Host species and individual

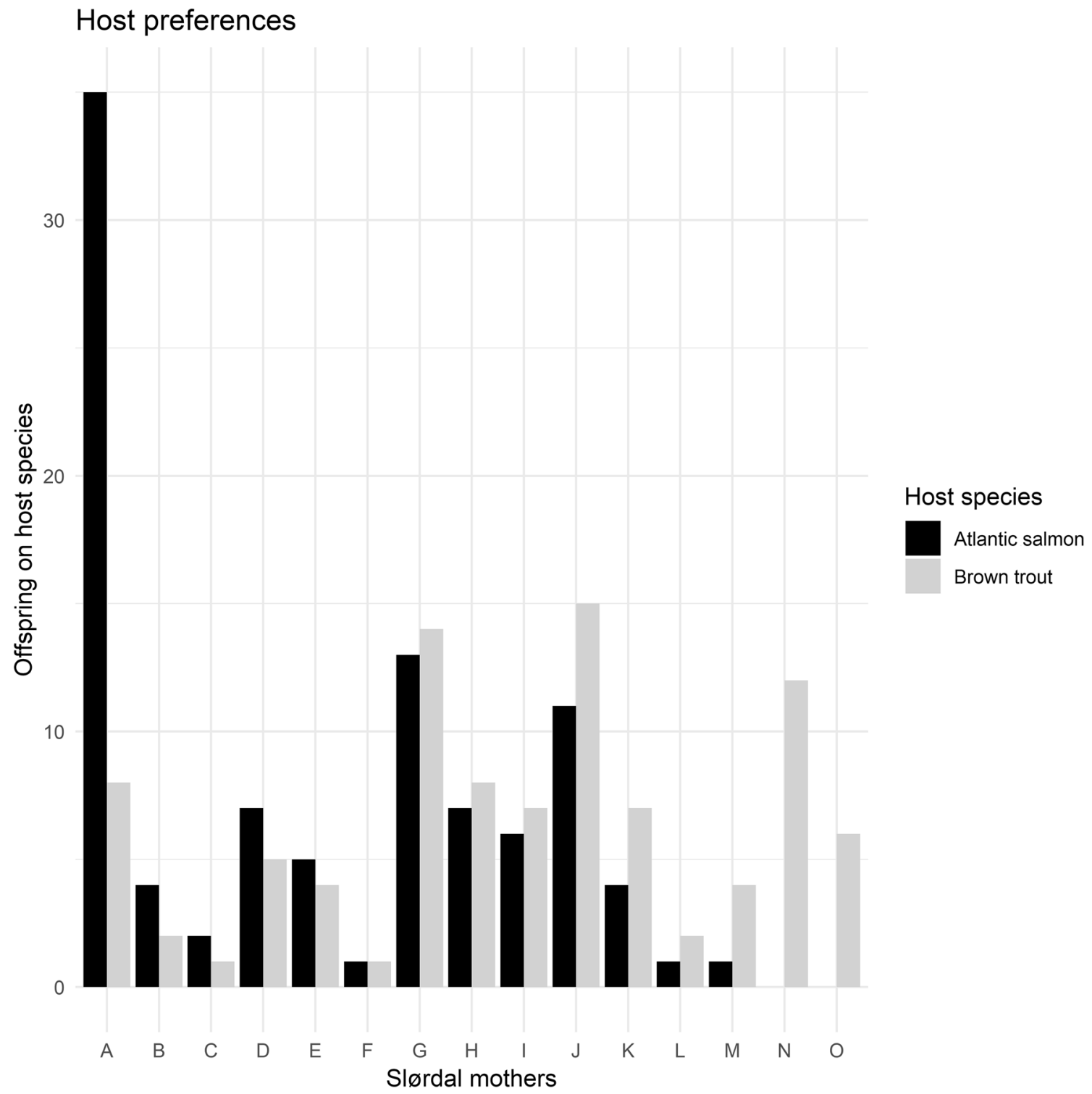

Fig. 5 Bar plot showing distribution of number of offspring from individual mothers of FPM from the river Slørdalselva among 100 offspring that developed on Atlantic salmon (black bars) and 100 offspring developed on brown trout (grey bars) 
hosts of a suitable species vary in terms of the conditions they provide for the developing glochidia. The variation in glochidial fitness is believed to be a result of host-parasite compatibility (Haag 2012), which in turn can depend on factors such as the genetic composition of the host and parasite, host factors (such as species, age, size, condition, infestation history, immune response, presence of other parasites), parasite factors (number of glochidia, virulence), environmental conditions (such as temperature) or a combination of these (Bauer and Vogel 1987; Combes 2000; Taeubert et al. 2010; Taeubert 2014; Marwaha et al. 2019). Nevertheless, our results show that the significantly higher mortalities, observed in the less suitable brown trout host compared to the principal Atlantic salmon host, were clearly a result of higher glochidial virulence on the less suitable host. These results are in line with Lievens et al. (2018), who observed that the microsporidian parasite $A$. rigaudi displayed higher virulence on the less suitable host $A$. franciscana, whereas on the suitable host (A. parthenogenetica) the parasitic virulence was moderate. They proposed that virulence could be related to the parasite's degree of specialisation.

Virulence is not an exclusive trait of the parasite, but it is dependent on the parasite's ability to inflict damage to the host, as well as the host's ability to defend itself against the parasite (Schmid-Hempel 2011; Råberg and Stjernman 2012). Parasitic virulence not only has a negative influence on host fitness, but it can also result in low fitness of the parasite (Rutrecht and Brown 2009; Lievens et al. 2018). In this study, we saw that a higher glochidial virulence in the brown trout hosts not only led to higher mortality of infested fish but also resulted in glochidial mortality. Parasitic virulence can also be a contributing factor that influences host species composition in ecosystems, because differential virulence on hosts can result in parasite-mediated competition (Price et al. 1988; Schall 1992; Thomas et al. 1995; Lefèvre et al. 2008). The host species whose fitness is most affected by parasitic virulence is at a selective disadvantage compared to the less affected one (Price et al. 1988; Schall 1992; Thomas et al. 1995; Lefèvre et al. 2008). For example, Schall (1992) examined how the presence of the malaria parasite (Plasmodium azurophilum) affected the distribution of two highly competitive species of Anolis lizard species (Anolis wattsi and Anolis gingivinus). He observed that in the presence of $P$. azurophilum (which most commonly infects $A$. gingivinus), A. wattsi was present, and in the absence of the parasite, only A. gingivinus was present. This showed how parasite-mediated competition between species influenced their distribution. The results of this study suggest that salmon could possibly have a selective competitive advantage over trout in areas with dense salmon-mussels, due to the lower virulence and thus higher survival of salmon.

Generally in any host-parasite interaction, parasite traits (infectivity and virulence) and host traits (susceptibility and resistance) are governed by the interactions between the host and parasite genotypes and the interaction between their genotypes and the environment (Ewald 1983; Mackinnon et al. 2002; Day and Burns 2003; Perlman and Jaenike 2003; Lambrechts et al. 2006; Salvaudon et al. 2007). When there are no environmental influences, genotype $\times$ genotype interactions between the host and the parasite influence the phenotype of the host-parasite interaction, and this can vary across different host-parasite combinations; i.e. some parasitic genotypes will result in higher virulence on some hosts, and some host genotypes will be more susceptible to some parasitic infections (Engel and Wächtler 1989; Peever et al. 2000; Carius et al. 2001; Lambrechts et al. 2005; Salvaudon et al. 2005; Ebert 2008; Schmid-Hempel 2009; Taeubert et al. 2010; Schmid-Hempel 2011; Barribeau et al. 2014). Several authors have observed that unionid mussel species differ in their ability to infest different species/strains/populations of their fish hosts, and this was dependent on the interaction between a specific mussel population and the host fish species/strain/population (Engel and Wächtler 1989; Eckert 2003; Rogers et al. 2001; Taeubert et al. 2010; Douda et al. 2014, 2017; Schneider et al. 2017). For example, Engel and Wächtler (1989) examined the interaction between glochidia of different subspecies/strains of Unio crassus and their host fish Leuciscus leuciscus L. They observed that only the glochidia of Unio crassus crassus forma maximus were able to successfully metamorphose on this host, compared to U. crassus crassus which did not develop. Similar results have also been seen in other studies using M. margaritifera and Salmo trutta L. strains (Taeubert et al. 2010); Unio crassus and their hosts Phoxinus phoxinus, Cottus gobio (Schneider et al. 2017) and Squalius cephalus (Douda et al. 2014); Sinanodonta woodiana and hosts Rhodeus ocellatus (Douda et al. 2017), Epioblasma florentina walkeri and Etheostoma flabellare (Rogers et al. 2001); and Cyprogenia aberti and hosts Percina phoxocephala, Percina caprodes and Etheostoma radiosum (Eckert 2003). Some further examples from other host-parasite interactions, also showing differences in host and parasite traits, are Daphnia magna clones and Pasteuria ramosa (Carius et al. 2001; Decaestecker et al. 2003; Little et al. 2006; Ebert 2008), Biomphalaria glabrata and Schistosoma mansoni (Webster and Woolhouse 1998), Bombus terrestris and Crithidia bombi (Imhoof and SchmidHempel 1998), and Atlantic salmon with Caligus elongatus (MacKinnon et al. 1995), Aeromonas salmonicida, Vibrio salmonicida and Renibacterium salmoninarum (Fevolden et al. 1993). The difference in glochidial virulence observed in our study suggests a presence of host-parasite genotype $\times$ genotype interactions, and we believe that the aforementioned studies support our proposal that host-parasite genotypespecific interactions are an important underlying reason that determines the degree of glochidial virulence on the different salmonid hosts. 
Hosts are often infested with multiple parasitic genotypes of the same species, and the interaction between coinfecting parasitic genotypes also influences the degree of virulence (Taylor et al. 2005; Lagrue et al. 2011; Bose and Schulte 2014; Råberg 2014). This is because a host is a limited resource, and the presence of two or more parasitic genotypes could lead to competition for resources (Taylor et al. 2005; Lagrue et al. 2011; Råberg 2014; Klemme and Karvonen, 2019). A higher virulence as a result of coinfecting parasitic genotypes have been observed in several studies (Ebert and Mangin 1997; Davies et al. 2002; Klemme and Karvonen, 2019. Thus, the interaction between the coinfecting parasitic genotypes will govern the degree of the infectivity or virulence and will vary for different genotype $\times$ genotype combinations (Taylor et al. 2005; Lagrue et al. 2011; Bose and Schulte, 2014; Råberg, 2014; Klemme and Karvonen 2019). In our experiment, glochidia came from several mothers, which in turn were fertilised by several fathers (Wacker et al. 2018). It is therefore highly likely that both the salmonid host species were infested with glochidia with different genotypes, and this was an added factor to the host-parasite interaction outcome. We believe that hostparasite genotype-specific interactions are an important underlying mechanism that determines the degree of FPM glochidial virulence on the two different salmonid hosts and partly explain host specificity.

Host immune strategy, such as resistance or tolerance to parasitic infection, is another important factor that can influence the degree of parasitic virulence (Lambrechts et al. 2006; Schmid-Hempel 2011; Hall and Ebert 2012). In host-parasite studies, resistance is described as the ability to prevent or reduce a given parasite, and tolerance is the ability to limit the damage caused by a given parasite (Råberg et al. 2009; Best et al. 2014; Jackson et al. 2014; Råberg 2014; Klemme and Karvonen 2016; Kutzer and Armitage 2016; Adelman and Hawley 2017). Several studies have shown that host immune response to infection by the same parasite differs among different host species (Fustish and Millemann 1978; Ellis and Stapleton 1988; Thomas et al. 1995; Buchmann and Uldal 1997; Bailey et al. 2019). These differences have been observed among various salmonid species with bacterial diseases (Ellis and Stapleton 1988; Bailey et al. 2019; Saleh et al. 2019) as well as with parasites (Johnson and Albright, 1992; Buchmann and Uldal 1997; Fast et al. 2006) including M. margaritifera (Fustish and Millemann 1978). Fustish and Millemann (1978) examined the immune response in Chinook salmon and coho salmon to glochidial infestation. They observed that the more resistant host (coho salmon) displayed severe hyperplasia and sloughed off glochidia within 4.5 days. In comparison, the more susceptible host (Chinook salmon) only displayed slight gill hyperplasia. Severe gill hyperplasia results in a decrease in respiratory gill surface area, leading to impaired gas exchange for which salmonid host fish have no adaptation (Taeubert and Geist 2013; Strzyzewska et al. 2016). Furthermore, the results from a previous experiment (Marwaha et al. 2019) showed us that $0+$ brown trout were resistant to glochidial infestation, and the 'resistant' immune response led to a lower Fulton's condition factor. When a resistant host mounts a strong immune response, this can result in the host's own tissue being damaged or lower general host fitness. Moreover, resistant hosts may pay an energetic cost for being resistant. The higher virulence (mortality) we observed on brown trout could be a result of the host being resistant to glochidial infestation, as opposed to a higher degree of tolerance observed in Atlantic salmon which displayed a lower mortality. Typically high glochidial densities are associated with host mortalities (Treasurer et al. 2006; Taeubert and Geist 2013). However, we did not record this data in our experiment and are therefore unable to comment on the glochidial density-related mortalities of host fish.

Host suitability studies have shown that FPM populations display significant differences in host preference (Salonen et al. 2017; Taeubert and Geist 2017; Clements et al. 2018). However, it has not been clear if glochidia from an individual mother are able to successfully infest the different salmonid host species. The results of this study clearly show that mixed infestation on a population level is not explained by some mothers solely infesting trout and others solely infesting salmon. In fact, individual mothers from an FPM population with Atlantic salmon as the principal host were able to infest both the salmonid host species, but not with an equal number of larvae. In this study, we have only examined the effect of different mothers and not that of different fathers. Therefore, our data cannot exclude the possibility that offspring from individual fathers or parent pairs may have only infested either trout or salmon. FPMs are sperm casters, and female mussels obtain sperm via their inhalant siphon. A single mother can be fertilised by multiple males in a single breeding event (Young and Williams 1984b; Wacker et al. 2018), and the mothers in our study were also fertilised by several different males (Wacker et al. 2018) which might explain the observed variation in host specificity among offspring from the same mother.

In accordance with the Red Queen hypothesis (Koskella and Lively 2006; Rabajante et al. 2016; Anzia and Rabajente 2018), the tested salmon-mussel populations were best adapted to the most common host species in their habitat. Salmon- and trout-mussel populations not only display extreme host specificity and differences in genetic diversity but also differ in their timing of glochidial release and growth rates (Larsen 2002; Karlsson et al. 2014). It has been proposed that salmon- and trout-mussel populations have evolved entirely separately after the ice age, in concert with the respective colonisation history of their preferred host (Machordom et al. 2003). An alternative view is that salmon- and trout-mussels have a common colonisation history, with the observed differentiation a result of local adaptation (Wacker et al. 2019). 
The results of this study show a clear difference in host-dependent glochidial virulence, with higher virulence in the less suitable host. We believe that this is the first study to report species-dependent host mortality as a result of glochidial infestation. We propose that this was a result of the interactions between host-parasite genotypes and the host immune response. Our results indicate that glochidial infestation could possibly result in parasitemediated competition, because salmon would clearly have a fitness advantage (higher survival) over trout in areas of dense salmon-mussel populations. This study further showed that individual mothers infested both salmonid host species. Further studies to examine if offspring from individual fathers or parent pairs only infest either trout or salmon would improve our understanding of host-parasite compatibility. The FPM and their salmonid hosts provide a good model to study co-evolutionary interactions in a long-lived specialist parasite, which has a generation time that is almost 30 years longer than its host (Geist and Kuehn 2008). The results of this study highlight the importance of choosing the most suitable host when developing strategies for conserving endangered FPM populations and their host fish in the wild, as well as in captive breeding programmes. A further study that examines the differences in glochidial genotypes that infest salmon and trout, and their relation to virulence, would improve our understanding of genotype $\times$ genotype interactions and their influence on glochidial infectivity, virulence and host fitness.

Acknowledgements We would like to thank Tore Bjånesøy and Ragnhild Jakobsen at the FPM rearing station at Austevoll for maintenance and sampling of fish and mussels; Torveig Balstad, Line Eriksen and Merethe Hagen (NINA) for DNA extraction and genotyping; Uttara Naik Nimbalkar (Savitribai Phule Pune University) for help with data analysis. The project was an offshoot of the captive breeding programme of Margaritifera margaritifera run by the University of Bergen, Norway. It was funded by the Norwegian Directorate for Nature Management and Lerøy Vest AS.

Funding Open access funding provided by University of Bergen (incl Haukeland University Hospital).

\section{Declarations}

Conflict of interest The authors declare no competing interests.

Open Access This article is licensed under a Creative Commons Attribution 4.0 International License, which permits use, sharing, adaptation, distribution and reproduction in any medium or format, as long as you give appropriate credit to the original author(s) and the source, provide a link to the Creative Commons licence, and indicate if changes were made. The images or other third party material in this article are included in the article's Creative Commons licence, unless indicated otherwise in a credit line to the material. If material is not included in the article's Creative Commons licence and your intended use is not permitted by statutory regulation or exceeds the permitted use, you will need to obtain permission directly from the copyright holder. To view a copy of this licence, visit http://creativecommons.org/licenses/by/4.0/.

\section{References}

Adelman JS, Hawley DM (2017) Tolerance of infection: a role for animal behaviour, potential immune mechanisms, and consequences for parasite transmission. Horm Behav 88:79-86. https://doi.org/10. 1016/j.yhbeh.2016.10.013

Anzia EL, Rabajante JF (2018) Antibiotic-driven escape of host in a parasite-induced Red Queen dynamics. R Soc Open Sci 5:1-9. https://doi.org/10.1098/rsos.180693

Bailey C, Strepparava N, Wahli T, Segner H (2019) Exploring the immune response, tolerance and resistance in proliferative kidney disease of salmonids. Dev Comp Immunol 90:165-175. https://doi.org/ 10.1016/j.dci.2018.09.015

Barribeau SM, Sadd BM, du Plessis L, Schmid-Hempel P (2014) Gene expression differences underlying genotype-by-genotype specificity in a host-parasite system. PNAS 111:3496-3501. https://doi.org/10. 1073/pnas.1318628111

Bauer G (1987) Reproductive strategy of the freshwater pearl mussel Margaritifera margaritifera. J Anim Ecol 56:691-704. https://doi. org/10.2307/5077

Bauer G (2001) Life-history variation on different taxonomic levels of naiads. In: Bauer G, Wächtler K (eds) Ecology and Evolution of the Freshwater Mussels Unionoida, vol 145. Springer-Verlag, The Series Ecological Studies Berlin, Germany, pp 83-92

Bauer G, Vogel C (1987) The parasitic stage of the freshwater pearl mussel (Margaritifera margaritifera L.) I. Host response to glochidiosis. Arch Hydrobiol Suppl 76:393-402

Best A, White A, Boots M (2014) The coevolutionary implications of host tolerance. Evolution 68:1426-1435. https://doi.org/10.1111/ evo. 12368

Bieger A, Ebert D (2009) Expression of parasite virulence at different host population densities under natural conditions. Oecologia 160: 247-255. https://doi.org/10.1007/s00442-009-1297-x

Bose J, Schulte RD (2014) Testing GxG interactions between coinfecting microbial parasite genotypes within hosts. Front Genet 5:124. https://doi.org/10.3389/fgene.2014.00124

Buchmann K, Uldal A (1997) Gyrodactylus derjavini infections in four salmonids: comparative host susceptibility and site selection of parasites. Dis Aquat Org 28:201-209. https://doi.org/10.3354/ dao028201

Bull JJ (1994) Virulence. Evolution 48:1423-1437. https://doi.org/10. $1111 /$ j.1558-5646.1994.tb02185.x

Carius HJ, Little TJ, Ebert D (2001) Genetic variation in a host-parasite association: potential for coevolution and frequency-dependent selection. Evolution 55:1136-1145. https://doi.org/10.1111/j.00143820.2001.tb00633.x

Chowdhury MMR, Marjomäki TJ, Taskinen J (2019, 2019) Effect of glochidia infection on growth of fish: freshwater pearl mussel Margaritifera margaritifera and brown trout Salmo trutta. Hydrobiologia. https://doi.org/10.1007/s10750-019-03994-4

Clements EA, Thomas R, Adams CE (2018) An investigation of salmonid host utilization by the endangered freshwater pearl mussel (Margaritifera margaritifera) in north-west Scotland. Aquat Conserv Mar Freshwat Ecosyst 28:764-768. https://doi.org/10. $1002 /$ aqc. 2900

Combes C (2000) Introduction: parasites, hosts, questions. In: Poulin R, Morand S, Skorping A (eds) Evolutionary Biology of Host-Parasite Relationships: Theory Meets Reality. Elsevier, Amsterdam, pp 1-8

Davies CM, Fairbrother E, Webster JP (2002) Mixed strain schistosome infections of snails and the evolution of parasite virulence. 
Parasitology 124:31-38. https://doi.org/10.1017/ s0031182001008873

Day T, Burns JG (2003) A consideration of patterns of virulence arising from host-parasite coevolution. Evolution 57:671-767. https://doi. org/10.1111/j.0014-3820.2003.tb01558.x

Decaestecker E, Vergote A, Ebert D, De Meester L (2003) Evidence for strong host clone-parasite species interactions in the Daphnia microparasite system. Evolution 57:784-792. https://doi.org/10. 1111/j.0014-3820.2003.tb00290.x

Dick CW, Patterson BD (2007) Against all odds: explaining high host specificity in dispersal-prone parasites. Int J Parasitol 37:8-9. https:// doi.org/10.1016/j.ijpara.2007.02.004

Dodd BJ, Barnhart MC, Rogers-Lowery CL, Fobian TB, Dimock RV Jr (2005) Cross-resistance of largemouth bass to glochidia of unionid mussels. J Parasitol 91:1064-1072. https://doi.org/10.1645/GE511R.1

Douda K (2015) Host-dependent vitality of juvenile freshwater mussels: implications for breeding programs and host evaluation. Aquaculture 445:5-10. https://doi.org/10.1016/j.aquaculture.2015. 04.008

Douda K, Liu H-Z, Yu D, Rouchet R, Liu F, Tang Q-Y, Methling C, Smith C, Reichard M (2017) The role of local adaptation in shaping fish-mussel coevolution. Freshw Biol 62:1858-1868. https://doi. org/10.1111/fwb.13026

Douda K, Sell J, Kubíková-Peláková L, Horký P, Kaczmarczyk A, Mioduchowska M (2014) Host compatibility as a critical factor in management unit recognition: population-level differences in mussel-fish relationships. J Appl Ecol 54:1085-1095. https://doi. org/10.1111/1365-2664.12264

Dybdahl MF, Storfer A (2003) Parasite local adaptation: Red Queen versus Suicide King. Trends Ecol Evol 18:523-530. https://doi. org/10.1016/S0169-5347(03)00223-4

Ebert D (1994) Virulence and local adaptation of a horizontally transmitted parasite. Science 265:1084-1086. https://doi.org/10.1126/ science.265.5175.1084

Ebert D (2008) Host-parasite coevolution: insights from the Daphniaparasite model system. Curr Opin Microbiol 11:290-301. https:// doi.org/10.1016/j.mib.2008.05.012

Ebert D, Mangin KL (1997) The influence of host demography on the evolution of virulence of a microsporidian gut parasite. Evolution 51:1828-1837. https://doi.org/10.1111/j.1558-5646.1997.tb05106.

Eckert NL (2003) Reproductive biology and host requirement differences among isolated populations of Cyprogenia aberti (Conrad 1850). Southwest Missouri State University, Springfield, MS Thesis

Eilertsen L, Hellen BA, Johnsen GH, Kålås S (2018) Forslag til ny soneforvaltning for arealbruk i Oselvvassdraget. Rådgivende Biologer AS, rapport 2464. ISBN Rådgivende Biologer AS, rapport.

Ellis AE, Stapleton KJ (1988) Differential susceptibility of salmonid fishes to furunculosis correlates with differential serum enhancement of Aeromonas salmonicida extracellular protease activity. Microb Pathog 4:299-304. https://doi.org/10.1016/0882-4010(88)90090-3

Engel H, Wächtler K (1989) Some peculiarities in developmental biology of two forms of freshwater bivalve Unio crassus in northern Germany. Arch Hydrobiol 115:441-450

Ewald PW (1983) Host-parasite relations, vectors, and the evolution of disease severity. Annu Rev Ecol Syst 14:465-485 https://www. jstor.org/stable/2096982

Fast MD, Muise DM, Easy RE, Ross NW, Johnson SC (2006) The effects of Lepeophtheirus salmonis infections on the stress response and immunological status of Atlantic salmon (Salmo salar). Fish Shellfish Immunol 21:228-241. https://doi.org/10.1016/j.fsi.2005. 11.010

Fevolden SE, Nordmo R, Refstie T, Røed KH (1993) Disease resistance in Atlantic salmon (Salmo salar) selected for high or low responses to stress. Aquaculture 109:215-224. https://doi.org/10.1016/00448486(93)90164-T

Filipsson K, Brijs J, Näslund J, Wengström N, Adamsson M, Závorka L, Österling ME, Höjesjö J (2017) Encystment of parasitic freshwater pearl mussel (Margaritifera margaritifera) larvae coincides with increased metabolic rate and haematocrit in juvenile brown trout (Salmo trutta). Parasitol Res 116:1353-1360. https://doi.org/10. 1007/s00436-017-5413-2

Fustish CA, Millemann RE (1978) Glochidiosis of salmonid fishes. II. Comparison of tissue response of Coho and Chinook salmon to experimental infection with Margaritifera margaritifera (L.) (Pelecypoda: Margaritiferidae). J Parasitol 64:155-157 https:// www.jstor.org/stable/3279631

Gandon S, Michalakis Y (2002) Local adaptation, evolutionary potential and host-parasite coevolution: interactions between migration, mutation, population size and generation time. J Evol Biol 15:451-462. https://doi.org/10.1046/j.1420-9101.2002.00402.x

Garlie S (2010) Utvikling av mikrosatelitt multipleks PCR for genetiske studier av Margaritifera margaritifera. Høgskolen i Hedmark

Geist J, Kuehn R (2008) Host-parasite interactions in oligotrophic stream ecosystems: the roles of life history strategy and ecological niche. Mol Ecol 17:997-1008. https://doi.org/10.1111/j.1365-294X.2007. 03636.x

Geist J, Moorkens E, Killeen I, Feind S, Stoeckle BC, Connor ÁO, Kuehn R (2018) Genetic structure of Irish freshwater pearl mussels (Margaritifera margaritifera and Margaritifera durrovensis): validity of subspecies, roles of host fish, and conservation implications. Aquat Conserv Mar Freshwat Ecosyst 28:923-933. https://doi.org/ $10.1002 /$ aqc. 2913

Geist J, Rottmann O, Schröder W, Kuehn R (2003) Development of microsatellite markers for the endangered freshwater pearl mussel Margaritifera margaritifera L. (Bivalvia: Unionoidea). Mol Ecol 3: 444-446. https://doi.org/10.1046/j.1471-8286.2003.00476.x

Haag WR (2012) North American freshwater mussels: natural history, ecology, and conservation. Cambridge University Press, Cambridge, UK

Hall MD, Ebert D (2012) Disentangling the influence of parasite genotype, host genotype and maternal environment on different stages of bacterial infection in Daphnia magna. Proc R Soc B 279:31763183. https://doi.org/10.1098/rspb.2012.0509

Hastie LC, Young MR (2001) Freshwater pearl mussel (Margaritifera margaritifera) glochidiosis in wild and farmed salmonid stocks in Scotland. Hydrobiologia 445:109-119. https://doi.org/10.1023/A: 1017588222480

Horký P, Douda K, Maciak M, Závorka L, Slavík O (2014) Parasiteinduced alterations of host behaviour in a riverine fish: the effects of glochidia on host dispersal. Freshw Biol 59:1452-1461. https:// doi.org/10.1111/fwb.12357

Hruška J (1999) Nahrungsansprüche der Flußperlmuschel und deren halbnatürliche Aufzucht in der Tschechischen Republik. Heldia 4: 69-79

Hurst CN, Bartholomew JL (2012) Ceratomyxa shasta genotypes cause differential mortality in their salmonid hosts. J Fish Dis 35:725-732. https://doi.org/10.1111/j.1365-2761.2012.01407.x

Imhoof B, Schmid-Hempel P (1998) Single-clone and mixed-clone infections versus host environment in Crithidia bombi infecting bumblebees. Parasitology 114:331-336. https://doi.org/10.1017/ s0031182098003138

Jackson JA, Hall AJ, Friberg IM, Ralli C, Lowe A, Zawadzka M, Turner AK, Stewart A, Birtles RJ, Paterson S, Bradley JE, Begon M (2014) An immunological marker of tolerance to infection in wild rodents. PLoS Biol 12:1-13. https://doi.org/10.1371/journal.pbio.1001901

Jansen W, Bauer G, Zahner-Meike E (2001) Glochidial mortality in freshwater mussels. In: Bauer G, Wächtler K (eds) Ecology and Evolution of the Freshwater Mussels Unionoida, vol 145. 
Springer-Verlag, The Series Ecological Studies Berlin, Germany, pp 186-211

Johnsen GH, Tveranger B, Kålås S (2008) Dokumentasjonsvedlegg til søknad om konsesjon for uttak av vann ved Marine Harvest Norvay AS Avd. Slørdal (reg. nr. ST/Si 0004). Konsekvensutredning for fisk og elvemusling Rådgivende Biologer AS, rapport 1123. ISBN 978- 82-7658-622-0.

Johnson SC, Albright LJ (1992) Comparative susceptibility and histopathology of the response of naive Atlantic, chinook and coho salmon to experimental infection with Lepeophtheirus salmonis (Copepoda: Caligidae). Dis Aquat Org 14:179-193. https://doi.org/10.3354/ dao014179

Kalinowski ST, Taper ML, Marshall TC (2007) Revising how the computer program CERVUS accommodates genotyping error increases success in paternity assignment. Mol Ecol 16:1099-1106. https:// doi.org/10.1111/j.1365-294X.2007.03089.x

Kaltz O, Shykoff JA (1998) Local adaptation in host-parasite systems. Heredity 81:361-370. https://doi.org/10.1046/j.1365-2540.1998. 00435.x

Karlsson S, Larsen BM, Eriksen L, Hagen M (2013) Four methods of nondestructive DNA sampling from freshwater pearl mussels Margaritifera margaritifera L. (Bivalvia: Unionoida). Freshw Sci 32(2):525-530. https://doi.org/10.1899/12-079.1

Karlsson S, Larsen BM, Hindar K (2014) Host-dependent genetic variation in freshwater pearl mussel (Margaritifera margaritifera L.). Hydrobiologia 735:179-190. https://doi.org/10.1007/s10750-0131679-2

Karlsson S, Larsen BM, Balstad T, Eriksen L, Hagen M (2016) Elvemusling - evaluering av en kultiveringsmetode. NINA Rapport 1257

Kat PW (1984) Parasitism and the Unionacea (Bivalvia). Biol Rev 59: 189-207. https://doi.org/10.1111/j.1469-185X.1984.tb00407.x

Klemme I, Karvonen A (2016) Vertebrate defence against parasites: interactions between avoidance, resistance and tolerance. Ecol Evol 7: 561-571. https://doi.org/10.1002/ece3.2645

Klemme I, Karvonen A (2019) Within-host interactions shape virulencerelated traits of trematode genotype. J Evol Biol 32:572-579. https:// doi.org/10.1111/jeb.13438

Koskella B, Lively CM (2006) Advice of the rose: experimental coevolution of a trematode parasite and its snail host. Evolution 61:152159. https://doi.org/10.1111/j.1558-5646.2007.00012.x

Kutzer MAM, Armitage SAO (2016) Maximising fitness in the face of parasites: a review of host tolerance. Zoology 119:281-289. https:// doi.org/10.1016/j.zool.2016.05.011

Lagrue C, Kelly DW, Hicks A, Poulin R (2011) Factors influencing infection patterns of trophically transmitted parasites among a fish community: host diet, host-parasite compatibility or both? J Fish Biol 79: 466-485. https://doi.org/10.1111/j.1095-8649.2011.03041.x

Lambrechts L, Halbert J, Durand P, Gouagna LC, Koella JC (2005) Host genotype by parasite genotype interactions underlying the resistance of anopheline mosquitoes to Plasmodium falciparum. Malar J 4:18. https://doi.org/10.1186/1475-2875-4-3

Lambrechts L, Fellous S, Koella JC (2006) Coevolutionary interactions between host and parasite genotypes. Trends Parasitol 22:12-16. https://doi.org/10.1016/j.pt.2005.11.008

Larsen BM (2002) Overvåking av elvemusling Margaritifera margaritifera i Norge. Årsrapport 2001. NINA Oppdragsmelding 762.

Larsen BM, Hårsaker K, Bakken J, Barstad DV (2000) Elvemusling Margaritifera margaritifera i Steikjervassdraget og Figga, Nord Trøndelag. Forundersøkelse i forbindelse med planlagt rotenonbehandling. NINA Fagrapport 039. Trondheim: Norsk institutt for naturforskning

Larsen BM, Forseth T, Saksgård R (2012) Host specificity in freshwater pearl mussel Margaritifera margaritifera populations in Norway experimental studies. In: International Meeting on Biology and
Conservation of Freshwater Bivalves: Book of Abstracts. Instituto Politécnico de Braganza.

Lefèvre T, Roche B, Poulin R, Hurd H, Renaud F, Thomas F (2008) Exploiting host compensatory responses: the 'must' of manipulation? Trends Parasitol 24:435-439. https://doi.org/10.1016/j.pt. 2008.06.006

Leggett HC, Buckling A, Long GH, Boots M (2013) Generalism and the evolution of parasite virulence. Trends Ecol Evol 28:592-596. https://doi.org/10.1016/j.tree.2013.07.002

Lievens EJP, Perreau J, Agnew P, Michalakis Y, Lenormand T (2018) Decomposing parasite fitness reveals the basis of specialization in a two-host, two-parasite system. Evol Lett 2:390-405. https://doi.org/ $10.1002 /$ evl 3.65

Little TJ, Watt K, Ebert D (2006) Parasite-host specificity: experimental studies on the basis of parasite adaptation. Evolution 60:31-38. https://doi.org/10.1554/05-316.1

Machordom A, Araujo R, Erpenbeck D, Ramos MA (2003) Phylogeography and conservation genetics of endangered European Margaritiferidae (Bivalvia: Unionoidea). Biol J Linn Soc 78:235-252. https://doi.org/10.1046/j.1095-8312.2003.00158.x

MacKinnon BM, Bailey JK, O’Flynn FM, Friars GW (1995) Sea lice: can selection improve resistance? North Aquac 11:3

Mackinnon MJ, Gaffney DJ, Read AF (2002) Virulence in rodent malaria: host genotype by parasite genotype interactions. Infect Genet Evol 1:287-296. https://doi.org/10.1016/S1567-1348(02)00039-4

Marwaha J, Aase H, Geist J, Stoeckle BC, Kuehn R, Jakobsen PJ (2019) Host (Salmo trutta) age influences resistance to infestation by freshwater pearl mussel (Margaritifera margaritifera) glochidia. Parasitol Res 118:1519-1532. https://doi.org/10.1007/s00436-01906300-2

Marwaha J, Jensen KH, Jakobsen JJ, Geist J (2017) Duration of the parasitic phase determines subsequent performance in juvenile freshwater pearl mussels (Margaritifera margaritifera). Ecol Evol 7:1375-1383. https://doi.org/10.1002/ece3.2740

Meyers TR, Milleman RE (1977) Glochidiosis of salmonid fishes. I. Comparative susceptibility to experimental infection with Margaritifera margaritifera (L.) (Pelecypoda: Margaritanidae). J Parasitol 63:728-733. https://doi.org/10.2307/3279583

Nezlin LP, Cunjak RA, Zotin AA, Ziuganov VV (1994) Glochidium morphology of the freshwater pearl mussel (Margaritifera margaritifera) and glochidiosis of Atlantic salmon (Salmo salar): a study by scanning electron microscopy. Can J Zool 72:15-21. https://doi.org/10.1139/z94-003

Österling EM, Wengström N (2015) Test of the host fish species of a unionoid mussel: a comparison between natural and artificial encystment. Limnologica 50:80-83. https://doi.org/10.1016/j.limno.2014. 11.005

Peever TL, Liu YC, Cortesi P, Milgroom MG (2000) Variation in tolerance and virulence in the chestnut blight fungus-hypovirus interaction. Appl Environ Microbiol 66:4863-4869. https://doi.org/10. 1128/AEM.66.11.4863-4869.2000

Perlman SJ, Jaenike J (2003) Infection success in novel hosts: an experimental and phylogenetic study of Drosophila-parasitic nematode. Evolution 57:544-557. https://doi.org/10.1111/j.0014-3820.2003. tb01546.x

Poulin R (2007) Evolutionary ecology of parasite: second edition. Princeton, NJ: Princeton Univeristy Press https://doi.org/10.1515/ 9781400840809

Poulin R, Mouillot D (2003) Parasite specialization from a phylogenetic perspective: a new index of host specificity. Parasitology 126:473480. https://doi.org/10.1017/S0031182003002993

Price WP, Westoby M, Rice B (1988) Parasite-mediated competition: some predictions and tests. Am Nat 131:544-555 https://www. jstor.org/stable/2461743 
R Core Team (2017) R: A language and environment for statistical computing. R Foundation for Statistical Computing, Vienna, Austria https://www.R-project.org/

Rabajante JF, Tubay JM, Ito H, Uehara T, Kakishima S, Morita S, Yoshimura J, Ebert D (2016) Host-parasite Red Queen dynamics with phase-locked rare genotypes. Parasitology 2:1-7. https://doi. org/10.1126/sciadv. 1501548

Råberg L, Stjernman M (2012) The evolutionary ecology of infectious disease virulence. In: Damas G, Nelson R (eds) Ecoimmunology. Oxford University Press, New York, USA, pp 548-578

Råberg L (2014) How to live with the enemy: understanding tolerance to parasites. PLoS Biol 12:1-4. https://doi.org/10.1371/journal.pbio. 1001989

Råberg L, Graham AL, Read AF (2009) Decomposing health: tolerance and resistance to parasites in animals. Philosophical Transaction of the Royal Society B 364:37-49. https://doi.org/10.1098/rstb.2008. 0184

Read AF (1994) The evolution of virulence. Trends Microbiol 2:73-76. https://doi.org/10.1016/0966-842x(94)90537-1

Rogers SO, Watson BT, Neves RJ (2001) Life history and population biology of the endangered tan riffleshell (Epioblasma florentina walkeri) (Bivalvia: Unionidae). J N Am Benthol Soc 20:582-594. https://doi.org/10.2307/1468089

Rutrecht ST, Brown MJF (2009) Differential virulence in a multiple-host parasite of bumble bees: resolving the paradox of parasite survival? Oikos 118:941-949. https://doi.org/10.1111/j.1600-0706.2009. 17392.x

Saleh M, Montero R, Kumar G, Sughagar A, Friedl A, Köllner B, ElMatbouli M (2019) Kinetics of local and systemic immune cell responses in whirling disease infection and resistance in rainbow trout. Parasit Vectors 12:1-11. https://doi.org/10.1186/s13071019-3505-9

Salonen JK, Luhta P-L, Moilanen E, Oulasvirta P, Turunen J, Taskinen J (2017) Atlantic salmon (Salmo salar) and brown trout (Salmo trutta) differ in their suitability as hosts for the endangered freshwater pearl mussel (Margaritifera margaritifera) in northern Fennoscandian rivers. Freshw Biol 62:1346-1358. https://doi.org/10.1111/fwb. 12947

Salvaudon L, Héraudet V, Shykoff JA (2005) Parasite-host fitness tradeoffs change with parasite identity: genotype-specific interactions in a plant-pathogen system. Evolution 59:2518-2524. https://doi.org/10. 1111/j.0014-3820.2005.tb00965.x

Salvaudon L, Héraudet V, Shykoff JA (2007) Genotype-specific interactions and the trade-off between host and parasite fitness. BMC Evol Biol 7:1-10. https://doi.org/10.1186/1471-2148-7-189

Schall JJ (1992) Parasite-mediated competition in Anolis lizards. Oecologia 92:58-64. https://doi.org/10.1007/BF00317262

Schmid-Hempel P (2009) Immune defence, parasite evasion strategies and their relevance for 'macroscopic phenomena' such as virulence. Philos Trans R Soc B 364:85-98. https://doi.org/10.1098/rstb.2008. 0157

Schmid-Hempel P (2011) Evolutionary parasitology: the integrated study of infections, immunology, ecology, and genetics, 2nd edn. Oxford University Press, Oxford, UK

Schneider LD, Nilsson AP, Höjesjö J, Österling EM (2017) Local adaptation studies and conservation: parasite-host interactions between the endangered freshwater mussel Unio crassus and its host fish. Aquat Conserv Mar Freshwat Ecosyst 27:1261-1269. https://doi. org/10.1002/aqc. 2816

Smith DG (1976) Notes on the biology of Margaritifera margaritifera (Lin.) in Central Massachusetts. Am Midl Nat 96:252-256 https:// www.jstor.org/stable/2424588

Strayer L, Downing JA, Haag WR, King TL, Layzer JB, Newton TJ, Nichols SJ (2004) Changing perspectives on pearly mussels, North
America's most imperilled animals. BioScience 54:429-439. https:// doi.org/10.1641/0006-3568(2004)054[0429:CPOPMN]2.0.CO;2

Strzyzewska E, Szarek J, Babinska I (2016) Morphologic evaluation of the gills as a tool in the diagnostics of pathological conditions in fish and pollution in the aquatic environment: a review. Vet Med 61: 123-132. https://doi.org/10.17221/8763-VETMED

Taeubert J-E (2014) Host-parasite interactions in aquatic ecosystems the relationship between fishes and endangered freshwater mussels. (Doctoral dissertation, Technischen Universität München). Munich: TUM University Press.

Taeubert J-E, Geist J (2013) Critical swimming speed of brown trout (Salmo trutta) infested with freshwater pearl mussel (Margaritifera margaritifera) glochidia and implications for artificial breeding of an endangered mussel species. Parasitol Res 112:1607-1613. https://doi.org/10.1007/s00436-013-3314-6

Taeubert J-E, Geist J (2017) The relationship between the freshwater pearl mussel (Margaritifera margaritifera) and its hosts. Biol Bull 44:67-73. https://doi.org/10.1134/S1062359017010149

Taeubert J-E, Denic M, Gum B, Lange M, Geist J (2010) Suitability of different salmonid strains as hosts for the endangered freshwater pearl mussel (Margaritifera margaritifera L.). Aquat Conserv Mar Freshwat Ecosyst 20:728-734. https://doi.org/10.1002/aqc.1147

Taylor LH, Matthews L, Shaw DJ, Haydon DT (2005) Competitive suppression in mixed-clone parasite culture. Biol Lett 1:108-111. https://doi.org/10.1098/rsbl.2004.0256

Thomas F, Renaud F, Rousset F, Cezilly F, De Meeus T (1995) Differential mortality of two closely related host species induced by one parasite. Proc R Soc B 260:349-352. https://doi.org/10. 1098/rspb.1995.0103

Thomas GR, Taylor J, Garcia de Leaniz C (2014) Does the parasitic freshwater pearl mussel M. margaritifera harm its host? Hydrobiologia 735:191-201. https://doi.org/10.1007/s10750-013$1515-8$

Treasurer JW, Hastie LC, Hunter D, Duncan F, Treasurer CM (2006) Effects of (Margaritifera margaritifera) glochidial infection on performance of tank-reared Atlantic salmon (Salmo salar). Aquaculture 256:74-79. https://doi.org/10.1016/j.aquaculture.2006.02.031

Veiga JP, Salvador A, Merino S, Puerta M (1998) Reproductive effort affects immune response and parasite infection in a lizard: a phenotypic manipulation using testosterone. Oikos 82:313-318. https:// doi.org/10.2307/3546971

Wacker S, Larsen BM, Jakobsen PJ, Karlsson S (2018) High levels of multiple paternity in a spermcast mating freshwater mussel. Ecol Evol 8:8126-8134. https://doi.org/10.1002/ece3.4201

Wacker SW, Larsen BM, Karlsson S, Hindar K (2019) Host specificity drives genetic structure in a freshwater mussel. Sci Rep 9:1-7. https://doi.org/10.1038/s41598-019-46802-8

Watters GT, O'Dee SH (1999) Glochidia of the freshwater mussel lampsilis overwintering on fish hosts. J Molluscan Stud 65(4): 453-459. https://doi.org/10.1093/mollus/65.4.453

Webster JP, Woolhouse MEJ (1998) Selection and strain specificity of compatibility between snail intermediate hosts and their parasitic schistosomes. Evolution 53:1627-1634. https://doi.org/10.1111/j. 1558-5646.1998.tb02243.x

Young MR, Williams J (1984a) The reproductive biology of the freshwater pearl mussel Margaritifera margaritifera (Linn.) in Scotland. II. Laboratory studies, Archiv für Hydrobiologie 100:29-43

Young MR, Williams J (1984b) The reproductive biology of the freshwater pearl mussel Margaritifera margaritifera (Linn.) in Scotland. I. Field studies, Archiv für Hydrobiologie 99:405-422

Publisher's note Springer Nature remains neutral with regard to jurisdictional claims in published maps and institutional affiliations. 